\title{
Relationship between Environmental Factors and Rheumatic Heart Disease
}

\author{
Tina Christina Lumban Tobing ${ }^{1 * \mathbb{D}}$, Teddy Ontoseno ${ }^{2} \mathbb{D}$, Sri Rahayuningsih ${ }^{3} \mathbb{D}$, Ratna Akbari Ganie ${ }^{4}$, Yahwardiah Siregar ${ }^{5}$ (D) \\ ${ }^{1}$ Department of Child Health, Medical Faculty, Universitas Sumatera Utara, Medan, Indonesia; ${ }^{2}$ Department of Child Health, \\ Medical Faculty, Universitas Airlangga, Surabaya, Indonesia; ${ }^{3}$ Department of Child Health, Medical Faculty, Universitas \\ Padjajaran, Sumedang, Indonesia; ${ }^{4}$ Department of Clinical Pathology, Medical Faculty, Universitas Sumatera Utara, Medan, \\ Indonesia; ${ }^{5}$ Department of Biochemistry, Medical Faculty, Universitas Sumatera Utara, Medan, Indonesia
}

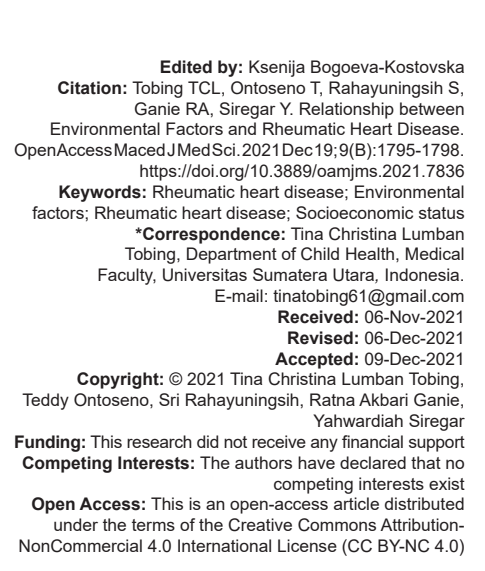

Introduction

Rheumatic fever (RF) and rheumatic heart disease (RHD) are the most common acquired heart diseases in children. The annual mortality rate in Asia is estimated to be $356,000-524,000$ [1], [2]. RF and RHD are complex diseases that were associated with genetic, virulency of the bacteria, and environmental factors [3]. The prevalence of RF and RHD tends to decrease as the socioeconomic status improves [4], [5], [6]. A wellplanned pharyngitis treatment program along with sanitation, health infrastructure, and socioeconomic status improvements have been proven to reduce the incidence of RF in other countries [7], [8].

Our objective is to determine the relationship between environmental factors and RHD.

\section{Methods}

An observational case-control study was conducted in the Department of Child Health, Haji
Adam Malik hospital Medan from April to June 2017. Subjects were obtained using consecutive sampling method. Children aged 5-18 years with diagnosis of RHD were enrolled in the case group while the control group consisted of healthy children. Demographic and anthropometric data were collected along with laboratory results. Environmental factors were obtained from each patient and his/her parents including parents' education background, monthly family income, water source, frequency of meat consumption, feasibility to buy clothes, house's dweller, household's fuel, and house's profiles. All subjects underwent echocardiography evaluation. Children with congenital heart disease were excluded from this study. Informed consent was obtained before conducting the procedure. This study had been approved by the Health Research Ethical Committee, Medical School, Universitas Sumatera Utara.

Statistical analysis was performed using Statistical Product and Service Solution. Chi-square and Fisher's exact tests were used to analyze the relationship between categorical variables. MannWhitney test was used to determine the relationship between categorical and continuous variables. The 
analysis was conducted at a 95\% confidence interval, and $p<0.05$ was considered significant.

\section{Results}

A total of 78 subjects were enrolled in this study. Male subjects were more dominant with the median age of 13.0 years (range $5.0-18.0$ years). Most subjects had normal antistreptolysin $O$ titer and C-reactive protein levels. Baseline characteristics of subjects were described in Table 1.

Table 1: Baseline characteristics of subjects

\begin{tabular}{ll}
\hline Characteristics & $\mathrm{n}=78$ \\
\hline Median age, year (range) & $13.0(5.0-18.0)$ \\
Gender, $\mathrm{n}(\%)$ & $43(55.1)$ \\
$\quad$ Male & $35(44.9)$ \\
Female & $31.6(10.61)$ \\
Mean body weight, $\mathrm{kg}(\mathrm{SD})$ & $139.0(60.0-173.0)$ \\
Median body height, $\mathrm{cm}$ (range) & $11.5(1.74)$ \\
Mean hemoglobin level, g/dL (SD) & $35.4(5.30)$ \\
Mean hematocrit, \% (SD) & $9.905,0(3.900,0-23.690,0)$ \\
Median leukocyte level, $\mathrm{mL}^{-1}$ (range) & $336.346,2(125.053,2)$ \\
Mean thrombocyte level, $\mathrm{mL}^{-1}$ (SD) & \\
ASTO level, $\mathrm{n}(\%)$ & $50(64.1)$ \\
$\leq 200 \mathrm{IU}$ & $28(35.9)$ \\
$>200 \mathrm{IU}$ & \\
CRP level, $\mathrm{n}(\%)$ & $52(66.7)$ \\
$\leq 0.7 \mathrm{mg} / \mathrm{L}$ & $26(33.3)$ \\
$>0.7 \mathrm{mg} / \mathrm{L}$ &
\end{tabular}

Most subject's parents went to senior high school and had monthly income at or lower than minimum regional standard. Median subject's house size was $60.0 \mathrm{~m}^{2}$ with median house's dwellers of 5.0 persons. Distribution of environmental factors was described in Table 2.

Parent's education, monthly family income, water source, consumption of meat, and feasibility to buy clothes were related with RHD in this study (Table 3).

\section{Discussion}

RHD is caused by immunologic response toward Streptococcus pyogenes infection. The infection usually manifests as tonsillopharyngitis. The $\mathrm{M}$ protein from bacteria's cell wall has similar structure (molecular mimicry) with several proteins in heart valve tissue. The molecular mimicry triggers autoimmune reaction and causes tissue damage [9].

A study in 2012 showed a similar result to our study. The highest prevalence of RHD was observed in children aged 5-16 years, followed by children aged more than 16 years. They found no RHD case in children aged under 5 years [10]. RF and RHD rarely occurred before 4 years old and even rarer before 2 years of age. The underlying cause of this condition is that the peak
Table 2: Distribution of subjects' environmental factors

\begin{tabular}{|c|c|}
\hline Characteristics & $\mathrm{n}=78$ \\
\hline \multicolumn{2}{|l|}{ Father's education, n (\%) } \\
\hline University & $8(10.3)$ \\
\hline Senior high school & $39(50.0)$ \\
\hline Junior high school & $26(33.3)$ \\
\hline Elementary school & $5(6.4)$ \\
\hline \multicolumn{2}{|l|}{ Mother's education, n (\%) } \\
\hline University & $9(11.5)$ \\
\hline Senior high school & $32(41.0)$ \\
\hline Junior high school & $30(38.5)$ \\
\hline Elementary school & $5(6.4)$ \\
\hline No formal education & $2(2.6)$ \\
\hline \multicolumn{2}{|l|}{ Monthly family income, n (\%) } \\
\hline >Minimum regional standard & $27(34.6)$ \\
\hline$\leq$ Minimum regional standard & $51(65.4)$ \\
\hline Median house size, $\mathrm{m}^{2}$ (range) & $60.0(24.0-180.0)$ \\
\hline Median house's dwellers, people (range) & $5.0(2.0-7.0)$ \\
\hline \multicolumn{2}{|l|}{ House floor material, $\mathrm{n}(\%)$} \\
\hline Bamboo & $2(2.6)$ \\
\hline Cement & $57(73.1)$ \\
\hline Ceramic & $19(24.4)$ \\
\hline \multicolumn{2}{|l|}{ House wall material, n (\%) } \\
\hline Palm leaves & $2(2.6)$ \\
\hline Wood & $7(9.0)$ \\
\hline Brick & $17(21.8)$ \\
\hline Wall & $52(66.7)$ \\
\hline \multicolumn{2}{|l|}{ Latrine possession, n (\%) } \\
\hline Yes & $76(97.4)$ \\
\hline No & $2(2.6)$ \\
\hline \multicolumn{2}{|l|}{ House's electricity, n (\%) } \\
\hline Available & $78(100.0)$ \\
\hline Not available & $0(0.0)$ \\
\hline \multicolumn{2}{|l|}{ Water source, n (\%) } \\
\hline Well & $37(47.4)$ \\
\hline Tap water & $41(52.6)$ \\
\hline \multicolumn{2}{|l|}{ Household's fuel, n (\%) } \\
\hline Firewood & $3(3.8)$ \\
\hline Charcoal & $3(3.8)$ \\
\hline Kerosene & $15(19.2)$ \\
\hline \multirow{2}{*}{\multicolumn{2}{|c|}{ Frequency of meat consumption, $n(\%)$}} \\
\hline & \\
\hline Once/week & $52(66.7)$ \\
\hline >Once/week & $26(33.3)$ \\
\hline \multicolumn{2}{|l|}{ Feasibility to buy clothes, n (\%) } \\
\hline 1 pair/year & $40(51.3)$ \\
\hline$>1$ pair/year & $38(48.7)$ \\
\hline \multicolumn{2}{|l|}{ Frequency of meal, n (\%) } \\
\hline$<3$ times daily & $7(9.0)$ \\
\hline$\geq 3$ times daily & $71(91.0)$ \\
\hline
\end{tabular}

incidence of tonsillopharyngitis occurs between 5 and 15 years of age [11]. There was no gender predilection in RHD as observed in this study.

Parent's education, monthly family income, water source, frequency of meat consumption, and feasibility to buy clothes were related with RHD in this study. Fathers who went to elementary and junior high school had higher risk of having children with RHD at 28.0 times $(p=0.032)$ and 15.75 times $(p=0.011)$, respectively, compared to fathers who went to university. Mothers who went to junior high school also had 7.0 times higher risk of having children with RHD $(p=0.026)$. Lower monthly family income would increase the risk of RHD. Family with monthly income at or lower than minimum regional standard had 3.68 times higher risk of having children with RHD ( $p=0.009)$ compared to family with monthly income higher than minimum regional standard. These findings are confirmed by several studies. A study in 2005 showed that poverty, overcrowding, and lower parent's education were risk factors of RHD [12]. Improvement in socioeconomic status was related to decreasing RHD prevalence in North India [13].

Frequency of meat consumption and feasibility to buy clothes also affected the incidence of RHD. Risk 
Table 3: Relationship between demographic and environmental factors and RHD

\begin{tabular}{|c|c|c|c|c|}
\hline Factors & RHD & No RHD & OR & $95 \% \mathrm{Cl}$ \\
\hline $\begin{array}{l}\text { Median age, year (range) } \\
\text { Gender, } \mathrm{n}(\%)\end{array}$ & & $\mathrm{N} / \mathrm{A}$ \\
\hline Male & $21(53.8)$ & $22(56.4)$ & $1.109 \mathrm{~b}$ & $0.454-2.708$ \\
\hline Female & $18(46.2)$ & $17(43.6)$ & & \\
\hline \multicolumn{5}{|l|}{ Father's education. n (\%) } \\
\hline University & $1(2.6)$ & $7(17.9)$ & Ref & Ref \\
\hline Senior high school & $12(41.0)$ & $23(59.0)$ & $4.870^{\mathrm{C}}$ & $0.545-43.523$ \\
\hline Junior high school & $18(46.2)$ & $8(20.5)$ & $15.750^{\circ *}$ & $1.652-150.141$ \\
\hline Elementary school & $4(10.3)$ & $1(2.6)$ & $28.000^{\circ *}$ & $1.350-580.591$ \\
\hline \multicolumn{5}{|l|}{$\begin{array}{l}\text { Mother's education. } \\
\mathrm{n}(\%)\end{array}$} \\
\hline University & $2(5.1)$ & $7(17.9)$ & Ref & Ref \\
\hline Senior high school & $12(30.8)$ & $20(51.3)$ & $2.100^{\circ}$ & $0.374-11.807$ \\
\hline Junior high school & $20(51.3)$ & $10(25.6)$ & $7.000^{c *}$ & $1.222-40.089$ \\
\hline Elementary school & $4(10.3)$ & $1(2.6)$ & $14.000^{\circ}$ & $0.944-207.597$ \\
\hline None & $1(2.6)$ & $1(2.6)$ & $3.500^{c}$ & $0.145-84.694$ \\
\hline \multicolumn{5}{|l|}{$\begin{array}{l}\text { Monthly family income. } \\
\mathrm{n}(\%)\end{array}$} \\
\hline $\begin{array}{l}>\text { Minimum regional } \\
\text { standard }\end{array}$ & $31(79.5)$ & $20(51.3)$ & $3.681^{b *}$ & $1.355-9.998$ \\
\hline $\begin{array}{l}\leq \text { Minimum regional } \\
\text { standard }\end{array}$ & $8(20.5)$ & $19(48.7)$ & & \\
\hline $\begin{array}{l}\text { Median house size. } \\
\mathrm{m}^{2} \text { (range) }\end{array}$ & $60.0(24.0-180.0)$ & $48.0(25.0-144.0)$ & $N / A^{a}$ & N/A \\
\hline $\begin{array}{l}\text { Median house's } \\
\text { dwellers, } \\
\text { person (range) }\end{array}$ & $5.0(2.0-7.0)$ & $5.0(3.0-7.0)$ & $N / A^{a}$ & $\mathrm{~N} / \mathrm{A}$ \\
\hline \multicolumn{5}{|l|}{$\begin{array}{l}\text { House floor material, } \\
\mathrm{n}(\%)\end{array}$} \\
\hline Bamboo & $1(3.1)$ & $1(3.7)$ & Ref & Ref \\
\hline Cement & $31(96.3)$ & $26(96.3)$ & $1.192^{c}$ & $0.071-20.011$ \\
\hline Ceramic & $7(87.5)$ & $12(92.3)$ & $0.583^{\circ}$ & $0.031-10.863$ \\
\hline \multicolumn{5}{|l|}{$\begin{array}{l}\text { House wall material, } \\
\text { n (\%) }\end{array}$} \\
\hline Palm leaves & $2(40.0)$ & $0(0.0)$ & Ref & Ref \\
\hline Wood & $3(60.0)$ & $4(100.0)$ & $N / A^{c}$ & N/A \\
\hline Brick & $10(83.3)$ & $7(100.0)$ & $N / A^{c}$ & $\mathrm{~N} / \mathrm{A}$ \\
\hline Wall & $24(92.3)$ & $28(100.0)$ & $N / A^{c}$ & N/A \\
\hline \multicolumn{5}{|c|}{ Latrine possession, $\mathrm{n}(\%)$} \\
\hline Yes & $39(100.0)$ & $37(94.9)$ & $N / A^{c}$ & N/A \\
\hline No & $2(5.1)$ & $0(0.0)$ & & \\
\hline \multicolumn{5}{|l|}{ House's electricity, n (\%) } \\
\hline Available & $39(100.0)$ & $39(100.0)$ & N/A & N/A \\
\hline Not available & $0(0.0)$ & $0(0.0)$ & & \\
\hline \multicolumn{5}{|l|}{ Water source, n (\%) } \\
\hline Well & $24(61.5)$ & $13(33.3)$ & $0.313^{b_{*}}$ & $0.124-0.790$ \\
\hline Tap water & $15(61.5)$ & $26(66.7)$ & & \\
\hline \multicolumn{5}{|l|}{ Household's fuel, n (\%) } \\
\hline Firewood & $2(5.1)$ & $1(2.6)$ & Ref & Ref \\
\hline Charcoal & $1(2.6)$ & $2(5.1)$ & $0.250^{\circ}$ & $0.008-7.542$ \\
\hline Kerosene & $12(30.8)$ & $3(7.7)$ & $2.000^{\circ}$ & $0.133-30.162$ \\
\hline Gas & $24(61.5)$ & $33(84.6)$ & $0.364^{\circ}$ & $0.031-4.245$ \\
\hline \multicolumn{5}{|l|}{$\begin{array}{l}\text { Consumption of meat, } \\
n(\%)\end{array}$} \\
\hline Once/week & $8(20.5)$ & $18(46.2)$ & $0.301^{\mathrm{b*}}$ & $0.111-0.819$ \\
\hline >Once/week & $31(79.5)$ & $21(538)$ & & \\
\hline \multicolumn{5}{|l|}{$\begin{array}{l}\text { Feasibility to buy clothes, } \\
\text { n (\%) }\end{array}$} \\
\hline 1 pair/year & $6(15.4)$ & $32(82.1)$ & $0.040^{\mathrm{b} *}$ & $0.012-0.131$ \\
\hline$>1$ pair/year & $33(84.6)$ & $7(17.9)$ & & \\
\hline \multicolumn{5}{|l|}{ Frequency of meal, $\mathrm{n}(\%)$} \\
\hline$<3$ times daily & $5(12.8)$ & $2(5.1)$ & $0.368^{c}$ & $0.067-2.021$ \\
\hline$\geq 3$ times daily & $34(87.2)$ & $37(94.9)$ & & \\
\hline
\end{tabular}

of RHD was lower in family which able to consume meat more than once per week (OR 0.3; $p=0.016$ ) and which able to buy clothes more than 1 pair per year (OR 0.04; $p<0.001$ ) compared to their counterparts (Table 3). These variables represent a family's socioeconomic status. The more frequent consumption of meat in a family and the more clothes a family can afford show better socioeconomic status. This allows the family to fulfil adequate nutritional support, complete access to healthcare facility including immunization, and good housing. These factors play important role in preventing streptococcal tonsillopharyngitis as the preceding event of RHD [14], [15].

Bad housing quality and low socioeconomic status will increase the susceptibility of RHD according to a study by Dobson et al., [16] In our study, family that used tap water as the water source was less likely to have children with RHD (OR 0.31; $p=0.013$ ). Families that can afford tap water pipeline generally have better housing quality and socioeconomic status. Better housing quality ensures good hygiene and prevents the incidence and transmission of tonsillopharyngitis.

We found no relationship between overcrowding and RHD in this study. This result is in contrast with several other studies. Okello stated that the risk of RHD increase in overcrowded population [17]. Similar result was also reported by Jaine [18]. These differences may be caused by the high population in Indonesia so that the amount of house's dwellers was similar between case and control groups.

Our study has several limitations. There is no strict classification of socioeconomic status in Indonesia; therefore, we only gathered factors which influence poverty based on Central Bureau of Indonesia Statistics criteria [19]. We did not match subjects in case and control groups and this might cause selection bias. Our data were not normally distributed thus preventing us to perform parametric study. Further studies with more subjects from several centres are needed to confirm the result of this study.

\section{Conclusion}

Parent's education, monthly family income, water source, frequency of meat consumption, and feasibility to buy clothes are related to RHD in children. Lower parent's education and monthly family income will increase the susceptibility of having children with RHD. Tap water usage, frequent consumption of meat, and feasibility to buy more clothes are protective factors of RHD.

\section{Acknowledgment}

The authors are grateful to all subjects and their families who participate in this study.

\section{References}

1. Carapetis JR. Rheumatic heart disease in Asia Circulation. 2008;118(25):2748-53. https://doi.org/10.1161/ circulationaha.108.774307

PMid:19106399

2. Kumar R, Raizada A, Aggarwal AK, Ganguly NK. 
A community-based rheumatic fever/rheumatic heart disease cohort: Twelve-year experience. Indian Heart J. 2002;54(1):54-8. PMid:11999089

3. Guilherme L, Köhler K, Kalil J. Rheumatic heart disease: Genes, inflammation and autoimmunity. Rheumatol Curr Res. 2012;4:1-5.

4. Ibrahim-Khalil S, Elhag M, Ali E, Mahgoub F, Hakiem S, Omer N, et al. An epidemiological survey of rheumatic fever and rheumatic heart disease in Sahafa Town, Sudan. J Epidemiol Community Health. 1992;46(5):477-9. https://doi.org/10.1136/ jech.46.5.477

PMid:1479314

5. Grover A, Dhawan A, lyengar SD, Anand IS, Wahi PL, Ganguly NK. Epidemiology of rheumatic fever and rheumatic heart disease in a rural community in northern India. Bull World Health Organ. 1993;71(1):59.

PMid:8440039

6. Cheng TO. How much of the recent decline in rheumatic heart disease in China can be explained by changes in cardiovascular risk factors? Int J Cardiol. 2009;132(3):300-2. https://doi. org/10.1016/j.ijcard.2008.06.087

PMid:18757106

7. Carapetis JR, Steer AC, Mulholland EK, Weber M. The global burden of group A streptococcal diseases. Lancet Infect Dis. 2005;5(11):685-94. https://doi.org/10.1016/ S1473-3099(05)70267-X

PMid:16253886

8. Seckeler MD, Hoke TR. The worldwide epidemiology of acute rheumatic fever and rheumatic heart disease. Clin Epidemiol. 2011;3:67-84. https://doi.org/10.2147/CLEP.S12977

PMid:21386976

9. Guilherme L, Faé K, Oshiro SE, Kalil J. Molecular pathogenesis of rheumatic fever and rheumatic heart disease. Expert Rev Mol Med. 2005;7(28):1-15. https://doi.org/10.1017/ S146239940501015X PMid:16336741

10. Prajapati D, Sharma D, Regmi PR, Khanal H, Baidya SG, Rajbhandari S, et al. Epidemiological survey of rheumatic fever, rheumatic heart disease and congenital heart disease among school children in Kathmandu valley of Nepal. Nepal Heart J. 2013;10(1):1-5.
11. Mota CC, Aiello VD, Anderson RH. Rheumatic fever. In: Pediatric Cardiology. $3^{\text {rd }}$ ed. Philadelphia, PA: Churchill Livingstone, Elsevier; 2010. p. 1091-113.

12. Meira ZM, Goulart EM, Colosimo EA, Mota CC. Long term follow up of rheumatic fever and predictors of severe rheumatic valvar disease in Brazilian children and adolescents. Heart. 2005;91(8):1019-22. https://doi.org/10.1136/hrt.2004.042762 PMid:16020588

13. Negi PC, Kanwar A, Chauhan R, Asotra S, Thakur JS, Bhardwaj AK. Epidemiological trends of RF/RHD in schoo children of Shimla in North India. Indian $J$ Med Res. 2013;137(6):1121-7

PMid:23852293

14. Feikin DR, Nguyen LM, Adazu K, Ombok M, Audi A, Slutsker L, et al. The impact of distance of residence from a peripheral health facility on pediatric health utilisation in rural western Kenya. Trop Med Int Health. 2009;14(1):54-61. https://doi. org/10.1111/j.1365-3156.2008.02193.x PMid:19021892

15. Al-Taiar A, Clark A, Longenecker JC, Whitty CJ. Physical accessibility and utilization of health services in Yemen. Int JHealth Geogr. 2010;9:38. https://doi.org/10.1186/1476-072X-9-38 PMid:20663146

16. Dobson J, Steer AC, Colquhoun S, Kado J. Environmenta factors and rheumatic heart disease in Fiji. Pediatr Cardiol. 2012;33(2):332-6. https://doi.org/10.1007/s00246-011-0139-x PMid:22057244

17. Okello E, Kakande B, Sebatta E, Kayima J, Kuteesa M, Mutatina B, et al. Correction: Socioeconomic and environmental risk factors among rheumatic heart disease patients in Uganda. PLoS One. 2013;7(8):e43917. https://doi.org/10.1371/journal. pone.0043917 PMid:22952810

18. Jaine $R$, Baker $M$, Venugopal K. Acute rheumatic fever associated with household crowding in a developed country. Pediatr Infect Dis J. 201;30(4):315-9. https://doi.org/10.1097/ INF.0b013e3181fbd85b PMid:20948456

19. Susanti N. Analysis of Poverty Indicator in Demak, 2017. [Analisis Indikator Kemiskinan Kabupaten Demak Tahun 2017]. $1^{\text {st }}$ ed. Demak: Badan Pusat Statistik Kabupaten Demak; 2017. 